\title{
Algorithm for empirical glycopeptide treatment in patients with hematologic malignancies and enterococcus faecium blood stream infection
}

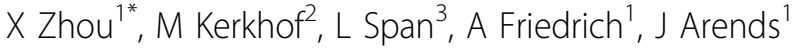 \\ From International Conference on Prevention \& Infection Control (ICPIC 2011) \\ Geneva, Switzerland. 29 June - 2 July 2011
}

\section{Introduction / objectives}

Enterococcus faecium has become a major cause of nosocomial infections especially in patients with hematologic malignancies. The aim of this study was to determine risk factors in those patients who are at risk of Enterococcus faecium blood stream infection (BSI) and should be considered for empirical treatment.

\section{Methods}

Retrospectively demographic, clinical and microbiological data in 33 patients with an E. faecium BSI were compared to 66 control patients during a 5-year period at the hematology ward. Multivariate logistic regression was used to explore the independent risk factors in order to develop a prognostic model to determine the risk of E. faecium BSI.

\section{Results}

Significant associations of E.faecium BSI were found with age, hospital stay prior to blood culture, duration of hospitalization 1 year before admission, fever prior to blood culture, severity and duration of neutropenia, CRP (C-reactive protein) at time of blood culture withdrawal, colonization with E. faecium prior to blood culture and diarrhea. E. faecium BSIs were found associated with more severe disease and higher mortality rates. Independent risk factors for E. faecium BSI were colonization with $E$. faecium 30 days prior to blood culture (OR 3.83; CI 1.1-12.8), fever > 1 day (4.02; 1.3$12.8)$, hospital stay prior to blood culture $>14$ days $(4.78 ; 1.3-18.0)$, age $>59$ years $(5.47 ; 1.6-18.2)$ and abdominal pain, diarrhea or neutropenia $(5.95 ; 1.1-31.4)$.

${ }^{1}$ Medical microbiology, University Medical Centre Groningen, Groningen, Netherlands

Full list of author information is available at the end of the article

\section{Conclusion}

Using prognostic modeling, risk stratification is possible for development of E. faecium BSI in patients with hematological malignancies. Empirical treatment should be considered in patients who are at high risk.

\section{Disclosure of interest}

None declared.

\section{Author details}

'Medical microbiology, University Medical Centre Groningen, Groningen, Netherlands. Epidemiology, University Medical Centre Groningen, Groningen, Netherlands. ${ }^{3}$ Hematology, University Medical Centre Groningen, Groningen, Netherlands.

Published: 29 June 2011

\section{doi:10.1186/1753-6561-5-S6-P49}

Cite this article as: Zhou et al:: Algorithm for empirical glycopeptide treatment in patients with hematologic malignancies and enterococcus faecium blood stream infection. BMC Proceedings 2011 5(Suppl 6):P49.

Submit your next manuscript to BioMed Central and take full advantage of:

- Convenient online submission

- Thorough peer review

- No space constraints or color figure charges

- Immediate publication on acceptance

- Inclusion in PubMed, CAS, Scopus and Google Scholar

- Research which is freely available for redistribution

\section{Biomed Central}

(c) 2011 Zhou et al; licensee BioMed Central Ltd. This is an open access article distributed under the terms of the Creative Commons Attribution License (http://creativecommons.org/licenses/by/2.0), which permits unrestricted use, distribution, and reproduction in any medium, provided the original work is properly cited. 